\title{
PERAN KEPALA SEKOLAH DALAM PENERAPAN MANAJEMEN BERBASIS SEKOLAH (MBS) DI SDIT JABAL NUR GAMPING, SLEMAN
}

\author{
Indra Haryanto Sindang Lurah, Haryanto \\ SSB Bintang Putra Mlati, Universitas Negeri Yogyakarta \\ indra_sent@yahoo.co.id, haryan62@yahoo.co.id
}

\begin{abstract}
Abstrak
Penelitian ini bertujuan: (1) mendeskripsikan peran kepala sekolah dalam penerapan manajemen berbasis sekolah (MBS), dan (2) mengetahui faktor pendukung dan penghambat dalam pelaksanaan MBS. Penelitian ini bersifat deskriptif. Subjek penelitian adalah SDIT Jabal Nur Gamping, Sleman, meliputi kepala sekolah, ketua yayasan, ketua komite sekolah, dan guru. Pengumpulan data menggunakan metode wawancara dan dokumentasi. Pemeriksaan keabsahan data menggunakan teknik triangulasi. Data dianalisis dengan menggunakan metode analisis deskriptif. Hasil dari penelitian ini adalah sebagai berikut. (1) SDIT Jabal Nur telah menerapkan MBS dan hal tersebut dapat diketahui melalui kemandirian yang dimiliki, baik kemandirian fisik maupun non-fisik, serta adanya partisipasi aktif stakeholder. (2) Peran kepala sekolah yang dominan dalam penerapan MBS adalah peran manajerial, karena kepala sekolah bisa memilih langsung siapa yang menjabat dalam struktur organisasi sekolah. (3) Peran sekolah dalam konteks MBS adalah sebagai motor penggerak bagi kehidupan sekolah. Peran tersebut adalah kepala sekolah sebagai pendidik, manajer, administrator, supervisor, pemimpin, wirausahawan, motivator, dan klimator. (4) Faktor penghambat dalam penerapan MBS adalah komunikasi yang belum berjalan dengan baik di sekolah serta kurangnya sosialisasi untuk penerapan MBS, sedangkan faktor pendukung adalah peran aktif warga sekolah dalam pelaksanaan MBS dan pemberiaan wewenang atau otonomi yang besar dari yayasan kepada sekolah.
\end{abstract}

Kata Kunci: manajemen berbasis sekolah, kepala sekolah

\section{THE ROLE OF THE HEADMASTER \\ IN SCHOOL-BASED MANAGEMENT IMPLEMENTATION AT SDIT JABAL NUR, GAMPING, SLEMAN}

\begin{abstract}
This study aimed (1) to describe the role of the headmaster in the Implementation of school-based management (SBM), and (2) to reveal both supporting and inhibiting factors in the implementation of SBM. This research is descriptive in nature. The subjects is SDIT Jabal Nur Gamping, Sleman, including the headmaster, the head of foundation, the head of school committee, and the teachers. The data collection used interview and documentation techniques, and they were validated through the triangulation technique. The data were analyzed by applying the descriptive analysis method. The results of this study are as follows. (1) SDIT Jabal Nur has Implemented the SBM and it could be seen from the independence both physically and non-physically at the staff as well as the stakeholders' active participation. (2) The dominant role of the headmaster in the implementation of SBM was the managerial role, since the headmaster could directly decide the ones who could be in the school organizational structure. (3) The school's role in the SBM context, is as a motor for motivating the school life. The role is that the school principal is as the educator, manager, administrator, supervisor, leader, entrepreneur, motivator, and climator. (4) The inhibiting factors in the implementation of SBM are the communication which does not run well at school and the lack of socialization of the implementation of the SBM, whereas the supporting factors are the active roles of the school members in Implementing the SBM and provision of authorities or autonomies bestowed from the organization to the school.
\end{abstract}

Keywords: school-based management, headmaster 


\section{Pendahuluan}

Sebagian sekolah, terutama di kotakota besar yang mempunyai murid pintar dan kreatif pasti menunjukkan peningkatan mutu pendidikan yang menggembirakan, namun sebagian besar lainnya masih memprihatinkan. Berdasarkan masalah di atas, maka berbagai pihak mempertayakan apa yang salah dalam penyelenggaraan pendidikan kita, ada berbagai faktor yang menyebabkan mutu pendidikan kita mengalami peningkatan secara tidak merata. Menurut Suaidin Usman (2012, p. 12) faktor tersebut pertama, kebijakan dan penyelenggaraan pendidikan nasional menggunakan pendekatan educational production function atau input-output analisis yang tidak dilaksanakan secara teratur. Pendekatan ini melihat bahwa lembaga pendidikan berfungsi sebagai pusat produksi yang apabila dipenuhi semua input yang diperlukan dalam kegiatan produksi tersebut, maka lembaga akan menghasilkan output yang dikehendaki. Pendekatan ini menganggap pendukung input pendidikan seperti pelatihan guru, pengadaan buku dan alat pelajaran, dan perbaikan sarana prasarana perbaikan lainnya dipenuhi, maka mutu pendidikan (output) secara otomatis akan terjadi dengan baik. Kedua, penyelenggaraan pendidikan nasional dilakukan secara birokratissentralistik, sehingga menyebabkan sekolah sebagai penyelenggaraan pendidikan yang tergantung pada keputusan birokrasi-birokrasi. Kadang-kadang birokrasi itu sangat panjang dan kebijakannya tidak sesuai dengan kondisi sekolah setempat. Maka akses dari birokrasi panjang dan sentralisasi itu, sekolah menjadi tidak mandiri, kurangya kreatifitas dan motivasi. Ketiga, minimnya peran masyarakat khususnya orang tua sisiwa dalam penyelenggaraan pendidikan, pratisipasi orang tua selama ini dengan sebatas pendukung dana, tapi tidak dilibatkan dalam proses pendidikan seperti mengambil keputusan, monitoring, evaluasi dan akuntabilitas, sehingga sekolah tidak memiliki beban dan tanggung jawab hasil pelaksanaan pendidikan kepada masyarakat/ orang tua sebagai stake holder yang berkepentingan dengan pendidikan.

Munculnya paradigma guru tentang manajemen berbasis sekolah yang bertumpu pada penciptaan iklim yang demokratis dan pemberian kepercayaan yang lebih luas kepada sekolah untuk menyelenggarakan pendidikan secara efisien dan berkualitas. Hal ini sangat memungkinkan dengan dikeluarkannya UU pemerintah no. 22 tahun 1999, selanjutnya diubah dengan UU no.32 tahun 2004 tentang otonomi daerah yang kemudian diatur oleh PP no. 33 tahun 2004 yaitu adanya penggeseran kewenangan dari pemerintah pusat ke pemerintah daerah dalam berbagai bidang termasuk bidang pendidikan kecuali agama, politik luar negeri, pertahanan dan keamanan, peradilan, moneter dan fiskal.

Sejak beberapa waktu terakhir, kita dikenalkan dengan pendekatan "baru" dalam manajemen sekolah yang diacu sebagai manajemen berbasis sekolah (school based management) atau disingkat MBS. Di mancanegara, seperti Amerika Serikat, pendekatan ini sebenarnya telah berkembang cukup lama. Pada 1988 American Association of School Administrators, National Association of Elementary School Principals, and National Association of Secondary School Principals, menerbitkan dokumen berjudul school based management, a strategy for better learning. Munculnya gagasan ini dipicu oleh ketidakpuasan atau kegerahan para pengelola pendidikan pada level operasional atas keterbatasan kewenangan yang mereka miliki untuk dapat mengelola sekolah secara mandiri. Umumnya dipandang bahwa para kepala sekolah merasa nirdaya karena terperangkap dalam ketergantungan berlebihan terhadap konteks pendidikan. Akibatnya, peran utama mereka sebagai pemimpin pendidikan semakin dikerdilkan dengan rutinitas urusan birokrasi yang menumpulkan kreativitas berinovasi (Dharma, 2003. "Manajemen Berbasis Sekolah". www.depdiknas.go.id).

Peran Kepala Sekolah

Pemimpin pendidikan (Kepala Sekolah) Memiliki delapan peran yang diakro- 
nimkan dengan EMASLEM-C, yaitu kepala sekolah sebagai: (1) educator/pendidik; (2) manajer; (3) administrator; (4) supervisor/ pengawas; (5) leader/pemimpin; (6) entrepreneur/kewirausahaan; (7) motivator; dan (8) climator/pencipta iklim kerja (Husaini Usman, 2006, p.249).

Secara rinci peran-peran keapal sekolah adalah sebagai berikut:

\section{Educator/Pendidik}

Bush (2006, p.79) menyatakan bahwa peran kepala sekolah sebagai pendidik adalah membentuk budaya pengajaran dan pembelajaran kondusif. Kepala sekolah melaksanakan pembinaan mental dengan membina tenaga kependidikan tentang halhal yang berkaitan dengan sikap batin dan watak. (Mulyasa, 2007, p.99). Dalam hal ini kelapa sekolah menciptakan iklim yang kondusif agar setiap tenaga kependidikan mampu melaksanakan tugasnya dengan baik, secara proporsional dan professional. Untuk itu, kepala sekolah hendaknya berusaha melengkapi sarana, prasarana dan sumber belajar agar dapat memberi kemudahan para guru dan siswa dalam tugas utamanya, yaitu belajar/mengajar.

\section{Manager}

Kepala sekolah adalah manajer di sekolahnya. Peran kepala sekolah sebagai manajer pendidikan menurut Wuradji (2009, p.100) adalah (1) menyusun perencanaan secara matang tentang tujuan dan strategi pencapaian tujuan, (2) melakukan pengorganisasian potensi sumber-sumber pendidikan yang ada, (3) melaksanakan kegiatan, dan (4) mengadakan control secara rutin terhadap pelaksanaan dan hasil pendidikan.

Menurut Husaini Usman (2006, p.305) selaku manajer, kewenangan utama kepala sekolah adalah mengambil keputusan. Karena peran tersebut, kepala sekolah dituntut untuk memiliki kemampuan untuk: (1) mengadakan prediksi masa depan sekolah, misalnya tentang kualitas yang diinginkan masyarakat, (2) melakukan inovasi dengan mengambil inisiatif dan ke- giatan-kegiatan yang kreatif untuk kemajuan sekolah, (3) menciptakan strategi atau kebijakan untuk mensukseskan pikiran-pikiran yang inovatif, (4) menyusun perencanaan, baik perencanaan strategis maupun perencanaan operasional, (5) menemukan sumber-sumber pendidikan dan menyediakan fasilitas pendidikan, (6) melakukan pengendalian terhadap pelaksanaan pendidikan dan hasilnya. Administrator. Kepala sekolah sebagai administrator memiliki hubungan yang sangat erat dengan berbagai aktifitas pengelolaan administrasi yang bersifat pencatatan, penyusunan dan pendokumentasian seluruh program sekolah Akhmad Sudrajat (2008, p.9). Jadi, kepala sekolah harus mampu melakukan pengelolaan: (1) pengajaran; (2) kepegawaian; (3) Kesiswaan; (4) sarana dan prasarana; (5) keuangan; (6) hubungan sekolah dan masyarakat. Kegiatan tersebut perlu dilakukan secara efektif dan efisien agar dapat menunjang produktifitas sekolah. Untuk itu kepala sekolah mampu menjabarkan kemampuan dalam tugas-tugas operasionalnya (Mulyasa, 2007, p.107).

\section{Supervisor/Pengawas}

Suharsimi Arikunto (2008, p.370) menyatakan bahwa supervisi merupakan istilah baru yang menunjuk pada suatu pekerjaan kepengawasan, tetapi sifatnya lebih manusiawi. Supervisi merupakan kegiatan pembinaan terhadap pertumbuhan pribadi dan profesi. Kegiatan utama supervisi adalah memberikan layanan kepada guru-guru baik secara individual maupun secara berkelompok dalam usaha memperbaiki pengajaran dengan tujuan memberikan pelayanan dan bantuan untuk mengembangkan situasi belajar mengajar yang dilakukan guru di dalam kelas.

\section{Leader/pemimpin}

Menurut Wahjosumidjo (2001, p.18), peran kepala sekolah sebagai pemimpin sekolah memiliki tanggung jawab menggerakan seluruh sumberdaya yang ada di sekolah yang ada sehingga melahirkan etos kerja dan produktifitas yang tinggi dalam 
mencapai tujuan. Hick (dalam buku Wahjosumidjo, 2001, p.21) berpendapat bahwa untuk dapat menjadin pemimpin sekolah yang baik, kepala sekolah harus: (1) adil, (2) mampu memberikan sugesti; (3) mendukung tercapainya tujuan; (4) mampu sebagai katalisator; (5) menciptakan rasa aman; (6) dapat menjadi wakil organisasi; (7) mampu menjadi sumber inspirasi; dan (8) bersedia menghargai.

Wahjosumidjo (2001, p.35) berpendapat bahwa perilaku kepala sekolah dalam menggerakan warga sekolah hendaknya terhindar sikap dan perbuatan yang bersifat memaksa atau bertindak keras. Namun sebaliknya, kepala sekolah memotivasi guru, staf dan siswa dalam melaksanakan tugasnya penuh semangat dan percaya diri. Kepala sekolah menyakinkan kepala sekolah agar percaya bahwa apa yang dilakukanya adalah benar.

\section{Enterpreneur/wirausahawan}

Permen 13 tahun 2007, tentang Standar Kompetensi Kepala Sekolah menyebutkan peran kewirausahaan kepala sekolah tercermin dalam komptensi yang harus dimiliki oleh kepala sekolah, yaitu: (1) menciptakan inovasi yang berguna bagi pengembangan sekolah/madrasah; (2) bekerja keras untuk mencapai keberhasilan sekolah sebagai organisasi pelajar yang efektif; (3) memiliki motovasi yang kuat untuk sukses dalam melaksanakan tugas pokok dan fungsinya sebagai pemimpin sekolah; (4) pantang menyerah dan selalu mencari solusi yang terbaik dalam menghadapi kendala yang ada; (5) memiliki naluri kewirausahaan dalam mengelola kegiatan produksi/jasa sekolah sebagai sumber balajar siswa.

\section{Motivator}

Sebagai peran motivator, kepala sekolah memiliki tugas mendorong, encouranging: bersikap hangat, bersahabat, menerima orang lain (Keating, 2006, p.10). Untuk itu kepala sekolah harus memiliki strategi memberikan motivasi kepada para tenaga kependidikan dalam melakukan berbagai tugas dan fungsinya (Mulyasa, 2007, p.120).

Salah satu teknik memotivasi adalah membangkitkan orang lemah menjadi kuat (Husaini, 2006, p 245). Kepala sekolah dapat membangkitkan motivasi dengan cara memberikan penghagaan bagi warga sekolah yang berpresatsi. Melalui penghargaan yang tepat, efektif, dan efisien, warga sekolah dirangsang untuk meningkatkan profesionalisme kerjanya secara positif dan produktif

\section{Climator/Pencipta Iklim Kerja.}

Sebagai seorang pencipta iklim kerja, peran kepala sekolah adalah menyakinkan dan menggerakan seluruh tenaga kependidikan dan siswa untuk menciptakan iklim kerja yang kondusif (Akhmad Sudrajat, 2008, p.11). Budaya iklim kerja kondusif akan memungkinkan seluruh warga sekolah lebih termotivasi untuk menciptakan kinerja yang lebih unggul serta upaya untuk peningkatan kompetensi secara terus menerus. Depdiknas (2006) menjelaskan peran kepala sekolah sebagai pencipta iklim kerja meliputi: (1) menata lingkungan fisik sekolah; (2) membentuk suasana dan iklim kerja; (3) menumbuhkan budaya sekolah. Sebagai penata fisik lingkungan sekolah hendaknya kepala sekolah mampu menciptakan lingkungan nyaman dengan menggerakkan semua warga sekolah untuk menciptakan dan memelihara kebersihan, ketertiban, keamanan dan kerindangan. Hal ini dapat terjadi jika kepala sekolah mampu menciptakan suasana kerja yang kondusif akademis.

\section{Konsep Dasar Kepemimpinan}

Kepemimpinan sebagai proses mempengaruhi kegiatan seseorang atau kelompok dalam usaha kearah pencapain tujuan dalam situasi tertentu (Sutisna Oteng, 1993, p.2). Tercapainya tujuan tersebut tercermin dalam produktifitas organisasi serta penampilan kinerja yang efektif. Sedangkan Fielder (1965, p.8) mengatakan bahwa "Leadership is the process of influencing group activities toward goal setting and goal; achieve- 
ment ". Kepemimpinan adalah proses aktivitas mempengaruhi kelompok atau group untuk menetapkan tujuan dan mencapai tujuan. Kemudian Keating (1986, p.9) menyatakan bahwa kepemimpinan adalah suatu proses dengan berbagai cara mempengaruhi orang atau sekelompok orang untuk mencapai tujuan yang bersama.

Kemampuan mempengaruhi, sebagai inti dari kepemimpinan tersebut, dilakukan oleh seseorang pemimpin dengan cara yang spesifik. Hal tersebut secara eksplisit sesuai dengan Yukl (1994, p.3) yang menyimpulkan bahwa:

Most definitions of leadership reflect the assumption that it involves a social enfluence process intentional influence is the exerted by one person over other people to structure the activities and relationship in a group or organization.

Kepemimpinan Kepala Sekolah

Kepala sekolah adalah seorang tenaga fungsional guru yang diberi tugas memimpin suatu sekolah di mana diselenggarakan proses belajar mengajar, atau tempat dimana terjadi interaksi antara guru yang member pelajaran dan murid yang menerima pelajaran (Wahjosumidjo, 2002, p.83). Sementara Rahman (2006, p.106) menyatakan bahwa "kepala sekolah adalah seorang guru (jabatan fungsional) yang diangkat untuk menduduki jabatan struktural (kepala sekolah) di sekolah.

Sebagai penanggung jawab pelaksanaan pendidikan, Starratt (2007, p.16) menyatakan bahwa kepala sekolah merupakan agen. Pertama adalah Negara. Kepala sekolah memiliki tanggung jawab untuk melaksanakan kebijakan dan haluan Negara dalam mengupayakan pendidikan paling baik bagi anak-anaknya di sekolah.

Sedang untuk menjadi pemimpin berkerampilan manusiawi, Made Pidarta (2004, p.223) menyatakan jika kepala sekolah: (1) memiliki kepribadian yang cocok melaksanakan tugas kepemimpinanya; (2) Memperhitungkan faktor situasi dalam melaksanakan tugas kepemimpinannya; (3) melakukan transaksi antara dia sebagai pe- mimpin dengan orang yang dipimpin, yaitu mengusahakan suatu kesepakatan bersama. Selanjutnya agar dapat membimbing dan mengontrol secara betul, maka kepala sekolah perlu memahami teknik-teknik yang dipakai dalam proses belajar mengajar, mulai dari perencanaan sampai pada evaluasi pembelajaran.

\section{Manajemen Berbasis Sekolah}

Gagasan Manajemen Berbasis Sekolah (MBS), dalam Bahasa Inggris SchoolBased Management pada dewasa ini menjadi perhatian para pengelolaan pendidikan, mulai dari tingkat pusat, provinsi, kabupaten/kota, sampai dengan tingkat sekolah. Sebagaimana dimaklumi, gagasan ini semakin mengemuka setelah dikeluarkannya kebijakan desentralisasi pengelolaan pendidikan seperti disyaratkan oleh UU Nomor 32 Tahun 2004. Produk hukum tersebut mengisyaratkan terjadinya pergeseran kewenangan dalam pengelolaan pendidikan dan melahirkan wacana akuntabilitas pendidikan.

Gagasan MBS perlu dipahami dengan baik oleh seluruh pihak yang berkepentingan (stakeholder) dalam penyelenggaraan pendidikan, khususnya sekolah, karena implementasi MBS tidak sekedar membawa perubahan dalam kewenangan akademik sekolah dan tatanan pengelolaan sekolah, akan tetapi membawa perubahan pula dalam pola kebijakan dan orientasi partisipasi orang tua dan masyarakat dalam pengelolaan sekolah.

\section{Alasan dan Tujuan MBS}

MBS di Indonesia yang menggunakan model Manajemen Peningkatan Mutu Berbasis Sekolah (MPMBS) muncul karena beberapa alasan sebagaimana diungkapkan oleh Nurkolis (2003, p.88) antara lain pertama, sekolah lebih mengetahi kekuatan, kelemahan, peluang dan ancaman bagi dirinya sehingga sekolah dapat mengoptimalkan pemanfaatan sumber daya yang tersedia untuk memajukan sekolahnya. Kedua, sekolah lebih mengetahui kebutuhannya. Ketiga, keterlibatan warga sekolah 
dan masyarakat dalam pengambilan keputusan dapat menciptakan transparansi dan demokrasi yang sehat. Menurut bank dunia, terdapat beberapa alasan diterapkannya MBS antara lain alasan ekonomis, politis, professional, efisiensi administrasi, finansial, prestasi siswa, akuntabilitas, dan efektifitas sekolah.

\section{Strategi Implementasi MBS}

MBS merupakan strategi peningkatan kualitas pendidikan melalui otoritas pengambilan keputusan dari pemerintah daerah ke sekolah. Dalam hal ini sekolah dipandang sebagai unit dasar pengembangan yang bergantung pada redistribusi otoritas pengambilan keputusan di dalamnya terkandung desentralisasi kewenangan yang diberikan kepada sekolah untuk membuat keputusan. Dengan demikian pada hakekatnya MBS merupakan desentralisasi kewenangan yang memandang sekolah secara individual. Sebagai bentuk alternatif sekolah dalam program desentralisasi bidang pendidikan, maka otonomi diberikan agar sekolah dapat leluasa mengelola sumber daya dengan mengalokasikannya sesuai dengan prioritas kebutuhan disamping agar sekolah lebih tanggap terhadap kebutuhan setempat

\section{Komponen MBS.}

Pusat penelitian dan pengembangan pendidikan agama dan keagamaan Depag RI (2007) lebih mendapatkan kata kunci diberlakukannya MBS, yaitu terletak pada empat komponen :

\section{Pelimpahan dan Pembagian Wewenang}

Desentralisasi kewenangan dilakukan dengan cara pelimpahan wewenang kepada aktor tingkat sekolah (kepala sekolah, guru, dan orang tua) untuk mengambil keputusan. Untuk mengoperasikan pelimpahan wewenang tersebut dibutuhkan adanya pembagian kewenangan yang jelas antara dewan Sekolah, pemerintah maupun para pelaksana pendidikan di sekolah.
Informasi Dua Arah dan Tanggung Jawab Untuk Kemajuan.

Informasi bersifat dua arah, yaitu top down (dari atas ke bawah) dan botom up (dari bawah ke atas) yang berisi tentang ide, isu-isu dan gagasan pelaksanaan pelaksanaan tugas serta kinerja, produktivitas sikap pegawai.

Bentuk dan Distribusi Penghargaan.

Penghargaan dalaam bentuk penggajian, insentif maupun penghargaan non material dalam bentuk internal (produk kerja, kepuasan kerja) maupun bentuk penghargaan eksternal (pujian, uang, dan penghargaan lainnya) akan terdistribusikan secara tepat terhadap individu-individu sesuai dengan kontribusi, partisipasi dan tingkat keberhasilannya di dalam pelaksanaan tugas yang diembannya.

Penetapan Standar Pengetahuan dan Keterampilan

Desentralisasi pengetahuan dan keterampilan berkaitan erat dengan pentapan standar kompetensi yang variatif sesuai dengan tuntutan yang ada serta memberikan peluang kepada pihak-pihak pelaksana pendidikan untuk senantiasa meningkatkan kompetensinya secara mandiri dengan penuh kesadaran dan bertanggung jawab terhadap kinerja yang dihasilkannya

Faktor Pendukung Keberhasilan Implementasi MBS.

Dalam buku pedoman manajemen berbasis sekolah dikaitkan bahwa keberhasilan pelaksanaan MBS sangat dipengaruhi oleh berbagai fakta,baik faktor internal maupun eksternal. Beberapa faktor pendukung tersebut pada garis besarnya mencakup sosialisasi peningkatan kualitas pendidikan, gerakan peningkatan kualitas pendidikan dan gotongroyong kekeluargaan, potensi sumber daya manusia, organisasi formal dan internal, organisasi profesi serta dukungan dunia usaha dan dunia industri. 


\section{Metode Penelitian}

Jenis Penelitian

Jenis penelitian yang digunakan dalam tulisan ini adalah Jenis penelitian kualitatif naturalistic. Penelitian ini dirancang untuk memahami fenomena peran kepemimpinan kepala sekolah dalam penerapan manajemen berbasis sekolah di SDIT Jabal Nur Gamping dalam situasi natural atau wajar, sebagaimana adanya, tanpa manipulasi, tanpa eksperimen, serta mengedepankan pola berfikir induktif. Artinya konsep, pandangan dan pengertian berasal dari bentuk data yang ada kemudian maju pada kesimpulan atau hasil akhir. Kegiatan dimulai dari pengumpulan data-data empiris, kemudian pengolahan data, dan diakhiri dengan kegiatan penentuan kesimpulan.

Tempat dan Waktu Penelitian

Tempat Penelitian Penelitian dilaksanakan di SDIT Jabal Nur Gamping Sleman dengan pertimbangan adalah sekolah tersebut termasuk sekolah favorit di kecamatan Gamping Kabupaten Sleman. Selain itu SDIT Jabal Nur Gamping Sleman memiliki prestasi UN Tertinggi di kecamatan Gamping kabupaten Sleman dalam satu tahun terakhir walaupun tidak merata pada semua siswa dalam mendapatkan hasil. Waktu Penelitian Penelitian dilaksanakan mulai bulan Juli - Oktober 2013.

Adapun pihak-pihak yang akan menjadi subjek penelitian adalah sebagai informan dalam penelitian ini meliputi: (1) informan kunci atau informan utama, yakni kepala sekolah SDIT Jabal Nur Gamping Sleman; (2) informan pendukung antara lain: Wakil Kepala Sekolah SDIT Jabal Nur, Guru SDIT Jabal Nur, Pengurus Yayasan, dan Komite Sekolah; (3) objek penelitian adalah kepemimpinan kepala sekolah SDIT Jabal Nur Gamping Sleman. Bagaimana peran kepemimpinan kepala sekolah dalam penerapan manajemen berbasis sekolah di SDIT Jabal Nur.

Teknik Pengumpulan Data

Dalam penelitian ini menggunakan dua strategi pengumpalan data yaitu me- tode wawancara dan kajian dokumen. Hal ini sesuai dengan tujuan dan keperluan penelitian yang akan mencari informasi sebanyak mungkin dari para informan. Untuk mengumpulkan informasi atau data yang diperoleh dari hasil observasi, wawancara dan kajian dokumen menjadi bahan penelitian. Metode wawancara; dalam metode wawancara, penelitian dapat melakukan wawancara berhadap-hadapan (face to face interview) atau melalui telephon dengan informan. Kajian dokumen; selama proses penelitian juga bisa mengumpulkan dokumen-dokumen kualitatif

\section{Instrumen Pengumpulan Data}

Instrumen penelitian adalah alat yang digunakan terkait pengumpulan data dalam penelitian. Adapun instrumen penelitian yang digunakan dalam penelitian ini adalah pedoman wawancara dan pedoman pencermatan dokumen.

Dalam penelitian kualitatif, penelitian bisa dilakukan sendiri atau dengan bantuan pihak lain merupakan alat pengumpul data utama. Pada saat melaksanakan pengumpulan data, penelitian dapat secara langsung mendatangi lokasi penelitian dan menggali informasi dan data selengkaplengkapnya guna memperdalam kajian penelitian.

\section{Teknik Analisis Data}

Moleong (2001) mengemukakan dalam proses analisis data dimulai dengan menelaah seluruh data yang tersedia dari berbagai sumber, yaitu wawancara, pengamatan, dokumentasi sebagai berikut. Setelah itu mengadakan reduksi data yang dilakukan dengan membuat abstraksi yaitu usaha membuat rangkuman, kemudian menyusunnya dalam satuan-satuan sambil membuat koding atau pengelolaan data. Dalam proses analisis data penelitian kualitatif terdapat 3 komponen penting, yaitu reduksi data, sajian data, dan penarikan kesimpulan atau verifikasi. Analisis yang digunakan dalam penelitian ini adalah model analisis interaktif, yaitu analisis yang dilakukan dalam bentuk interaktif dari ketiga komponen. 


\section{Hasil Penelitian dan pembahasan}

\section{Gambaran tentang SDIT Jabal Nur}

Visi SDIT Jabal Nur adalah "Menyiapkan generasi Islam yang unggul dalam ilmu pengetahuan dan teknologi serta seimbang Iman, Ilmu dan amalnya berdasarkan Al Quran dan As Sunnah".

Misi SDIT Jabal Nur adalah: "Menanamkan dasar Aqidah yang benar, Menanamkan kebiasaan beribadah secara benar, Membentuk perilaku Akhlaqul Karimah sesuai tuntunan Rasulullah SAW, Menanamkan \& Mengembangkan pola pikir yang cerdas, Menumbuhkan sikap kritis pada anak dalam suasana keterbukaan, Menanamkan dasar dasar ilmu pengetahuan \& teknologi, Menanamkan sikap mandiri".

Tujuan: "Menjadi sekolah unggulan yang menghasilkan generasi dengan karakter, pengetahuan, sikap dan perilaku Islami".

Manajemen Berbasis Sekolah di SDIT Jabal Nur: Manajemen Berbasis Sekolah (MBS) di SDIT Jabal Nur sebenarnya sudah lama diterapkan, karena banyak guru yang tidak menyadari akan arti dari manajemen berbasis sekolah membuat kepala sekolah, guru dan warga sekolah pada umumnya secara tidak sadar menerapkan MBS. Inti dari MBS sendiri adalah kemandirian dalam pengelolaan sekolah, otonomi sekolah untuk sekolah swasta khususnya SDIT Jabal Nur membuat MBS mudah diterapkan. Dalam setiap pelaksaan kegiatan sekolah ada dua hal yang menjadi rujukan yaitu peraturan dinas pendidikan dan sekolah / yayasan.

Peran Kepala Sekolah dalam Penerapan Manajemen Berbasis Sekolah di SDIT Jabal Nur.

Peran sebagai Pendidik dalam Penerapan Manajemen Berbasis Sekolah.

TR adalah kepala sekolah SDIT Jabal Nur Gamping Sleman sejak tanggal 2 Juli 2012. Beliau selain sebagai Kepala Sekolah juga sebagai guru mata pelajaran Bahasa Jawa. Pendidikan terakhir beliau adalah
Sarjana Psikologi. Alamat Rumah: Perum Kalasan Permai Sleman Yogyakarta. Jarak rumah ke SDIT Jabal Nur kurang lebih $20 \mathrm{~km}$. Jarak yang lumanyan jauh itu tidak menjadikan masalah kepala sekolah dalam mengembangakan dan menerapkan Manajemen Berbasis Sekolah di SDIT Jabal Nur.

Peran Ibu Kepala Sekolah Sudah baik sebagai seorang pendidik. Kepala sekolah secara umum berperan dalam memanage guru-guru dan mempunyai tugas banyak, salah satunya sebagai pendidik. Memberikan pengarahan kepada guru dan mendapatkan jam mengajar antar 6-8 jam perminggu (RS/21/8/2013).

Peran Kepala Sekolah sebagai pendidik baik. Sangat jelas sekali, karena untuk prospek SD Swasta seperti kita, seorang kepala sekolah juga mau tidak mau harus sebagai pengajar, karena disamping keterbatasan pengajar juga kepala sekolah mendapatkan jam mengajar (IR/20/08/2013).

Peran sebagai Manajer dalam Penerapan Manajemen Berbasis Sekolah

Peran utama TR sebagai manajer adalah mengelola tenaga kependidikan dan non kependidikan agar mampu melaksanakan tugasnya secara professional. Salah satu tugas yang dilaksanakan oleh TR, selaku kepala sekolah, adalah melakukan kegiatan pemeliharaan dan pengembangan profesi para guru, dalam hal ini TR memberikan kesempatan seluas-luasnya kepada guru dan karyawan dalam mengikuti kegiatan pengembangan profesi. Peran TR sebagai pengontrol dari semua kegiatan adalah hal yang utama sebagai seorang manajer. Berikut ini hasil wawancara dengan IR sebagai guru di SDIT Jabal Nur tentang peran kepala sekolah sebagai seorang manajer.

Sebagai manajer sangat vital peranya, karena hampir semua kegiatan sekolah di bawah manage dari kepala sekolah meskipun dalam pelaksanaanya ada kewenangan yang dilimpahkan serta pembagian tugas oleh guru guru yang lain (IR/23/08/ 2013).

Peran Kepala Sekolah sebagai manajer Sudah baik. Peran utama sebagai seorang 
manajer atau mengatur sebagai alur dalam kegiatan di sekolah ini, walaupun dari kegiatan tersebut juga dibantu oleh wakasek yang ada dan tetapi secara global semua kegiatan tersebut akan dipertanggungjawabkan kepada kepala sekolah, peran kepala sekolah (RS/21/8/2013).

Peran sebagai Adminitrator dalam Penerapan Manajemen Berbasis Sekolah

Walaupun belum semua adminitrasi sekolah dapat diselesaikan dengan baik, tetapi sebagian besar, bahkan pokok telah disusun. Dari RPS ini kemudian Tim (Wakil Kepala Sekolah) yang bersangkutan menyususun program kerja urusan-urusan sampai pada program kerja keuangan.

Peran Kepala sekolah sebagai administrator Baik. Peran yang sudah diambil oleh admin sekolah (HS/25/8/2013).

Dalam mengefektifkan kerja untuk adminitrasi sekolah TR berupaya untuk membagi tugas sejelas mungkin kepada guru dan karyawan sekolah. Berikut ini penjelas TR sebagai seorang administrator.

Karena sebagai kepala sekolah ternyata banyak sekali adminitrasi yang dikerjakan, tentunya saya punya asisten yaitu Tenaga Usaha (TU). Saya sebagai pemikir dan pelaksananya bagian TU itu yang kami lakukan di SDIT Jabal Nur, jadinya semuanya bisa terealisir, baik yang berkaitan dengan masyarakat sekitar, dinas terkait dan Yang bekaitan dengan yayasan juga, kita juga penuhi (TR/12/9/2013).

Peran sebagai Supervisor dalam Penerapan Manajemen Berbasis Sekolah,

TR selalu serius dalam melaksanakan pengawasan untuk meningkatkan mutu pendidikan di SDIT Jabal Nur. Supervisi yang dilakukan oleh TR meliputi supervise kegiatan, belajar mengajar, adminitrasi sekolah, kebersihan lingkungan, disiplin warga sekolah, iklim kerja, minat baca dan kegiatan sekolah. Setiap guru selalu disupervisi oleh TR dan hasil dari supervise tersebut TR serahkan kepada yayasan.

Peran Kepala Sekolah sebagai supervisor Baik. Mengadakan supervise 1 semester sekali dan melakukan penilain masuk ke kelas langsung. Untuk menilai cara mengajar guru dan persiapan sampai proses evaluasi (SW/29/8/2013).

Tetapi TR kebanyakan tidak melakukan supervisi secara menyeluruh, hanya sebagian saja yang dianggap penting. Aspek-aspek yang menjadi prioritas akan dibahas secara mendalam. Berikut ini adalah pernyataan RS sebagai wakasek kesiswaan di SDIT Jabal Nur.

Peran Kepala Sekolah sebagai supervisor Belum baik. Masalah komplek dari tugas dari kepala sekolah, untuk mengatur jalanya sekolah sangat penting dalam memberikan arahan kepada anak buahnya, dimana semisal tidak bisa mengarahkan anak buahnya, maka lembaga yang dipimpinya tidak berjalan dengan baik. Yang dibutuhkan kepala sekolah mempunyai dedikasi tinggi (RS/21/8/2013).

Peran sebagai Leader dalam Penerapan Manajemen Berbasis Sekolah,

Sebagai seorang pemimpin, peran TR adalah mempengaruhi, memobilisasi dan memberdayakan sumber daya yang ada secara efektif, kondusif, dan partisipatif danlam mencapai tujuan sekolah. TR yang mencoba menjadi contoh yang baik kepada guru dan karyawan di SDIT Jabal Nur menjadikan setiap tindakan yang dilakukan oleh TR menjadi contoh untuk bawahanya. Gaya kepemimpinan TR adalah gaya kepemimpinan modeling (contoh), harapan TR adalah setiap guru mampu mencontohnya apabila ada tindakana baik dan berani untuk tidak mencontoh perbuatan apabila itu tidak baik. Berikut ini adalah penjelasan TR tentang peran kepala sekolah sebagai pemimpin dalam penerapan MBS di SDIT Jabal Nur.

Saya sebagai seorang pemimpin mencoba memberi contoh, kalau bisa tidak banyak bicara. Saya mencoba meberikan contoh semampu saya untuk anak buah saya, walaupun saya banyak mempunyai kekurangan dan tetap saya akan berusaha. Misalnya dalam hal kedisiplinan, ibadah, sikap, bergaul dengan teman, saya banyak memberikan contoh dan nasehat. Dan Alhamdulillah guru guru disini adalah orang orang 
yang berpendidikan serta mudah menangkap apa yang saya mau, apabila ada hal yang belum benar saya mencoba memberikan nasehat sebaik mungkin dan tidak akan menyakiti (TR/12/9/2013).

Peran sebagai Enterpreneur dalam Penerapan Manajemen Berbasis Sekolah

Jiwa kewirausahawan TR dalam penerapan manajemen berbasis sekolah antara lain dengan menciptakan inovasi yang beguna untuk kemajuan dan perkembangan sekolah. Banyak terobosan yang dilakukan oleh TR dalam pengembangan Kewirausahaan ini. Berikut ini adalah pernyataan NA sebagai guru senior di SDIT Jabal Nur.

Peran kepala sekolah sebagai enterprenuer Cukup baik. Kepala sekolah menjaga nama baik sekolah terutama prestasi siswa yang telah dimiliki, serta mengusahan kegiatan dalam wirausaha siswa seperti kegiatan dihari rabu yang diberi nama market day, itu adalah jual beli yang ada dilingkungan sekolah (NA/22/08/2013).

TR masih berusaha mencari solusi dalam pemecahan untuk kewirausaha yang ada di SDIT Jabal Nur supaya menjadi lebih baik tanpa ada perbedaan pendapat dengan yayasan yang menaunginya. Dengan ada permasalahan seperti itu maka TR dituntut untuk kreatif dan inovatif supaya siswa bisa memperoleh pelajaran kewirausahaan. Berikut ini pernyataan TR dalam peran kepala sekolah sebagai entrepreneur.

Kalau yang ada di SDIT Jabal Nur, kita baru ada koperasi siswa atau koperasi sekolah, kita menyiapkan semua peralatan yang dibutuhkan oleh siswa, dan itu yang ada bertanggungjawab disana yaitu bagain koperasi, dari sisi keuntungan belum terlalu besar, untuk waktu depan kita akan tingkatan lagi tidak hanya keperluan siswa, tetapi berkaitan dengan kebutuhan makan. Dimana disini ada keperluan tentang makan karena sini kita ada makan siang yang dimana kebutuhan semua bahan makanan bisa dibeli dikoperasi. Untuk wirausaha ini kita juga mendidik siswa kita untuk menjadi wirausaha, setiap rabu disekolah kami ada yang namanya market day, jadi anak anak diSDIT jabal Nur tidak boleh jajan dan setiap hari rabu siswa siswa di SDIT Jabak Nur ada yang berjual, kemudian penjual adalah siswa setiap kelas dan digilir berjualanya, Alhamdulillah anak anak paham dalam berjualanya (TR/12/9/2013).

Peran Sebagai Motivator dalam Penerapan Manajemen Berbasis Sekolah

Tingkat keberhasilan guru dalam menyelesaikan tugasnya harus mendapatkan perhatian lebih dari seorang pemimpin. Sebagai seorang motivator TR dituntut untuk selalu memberikan motivasi kepada bawahan agar selalu semangat dalam bekerja. Dukungan secara fisik maupun psikis yang diberikan TR kepada guru dan karyawan SDIT Jabal Nur sangat berpengaruh dengan hasil kerja yang yang diadapat. motivasi dari kepala sekolah perlu Berikut ini adalah pernyataan TR yang berperan sebagai motivator.

Setiap ada guru yang inggin meningkatkan diri saya mencoba untuk mendukung, dan apabila ada guru yang berprestasi kita juga memberikan penghargaan minimal dari kata-kata, tidak dengan seterusnya materi. Berkaitan dengan keuangan yang belum ada anggaran, jadi ada semangat untuk karyawan untuk meningkatkan diri (TR/12/9/2013).

Dalam suatu pekerjaan yang diterima oleh guru dan karyawan TR selalu memberikan target dalam penyelesaianya. Target-target tersebut yang menjadi beban dan tekanan kepada guru untuk segera menyelesaikan dalam batas waktu yang telah ditentukam. TR yang memberikan tugas dan targetan yang diinginkan tidak begitu saja lepas dari pekerjaan bawahnya, motivasi untuk guru dan karyawan dalam meneyelesaikan tugas tersebut pasti TR berikan.

Peran sebagai Climator dalam Penerapan Manajemen Berbasis Sekolah

Bagi TR iklim kerja yang baik bisa menumbuhkan semangat kerja yang menyenangkan bagi guru dan karyawan yang berkerja, berikut ini penjelasanya. 
Peran saya sebagai climator mencoba untuk memberikan iklim kerja di SDIT Jabal Nur yang menyenangkan, itu yang saya lakukan dan usahankan,walaupun itu belum maksimal 100 persen (TR/12/9/ 2013).

Bedasarkan penjelasan singkat TR tersebut bahwa TR berusaha memberikan iklim kerja yang menyenangkan kepada seluruh guru dan karyawan yang bekerja di SDIT Jabal Nur, pekerjaan yang berat dan jam kerja yang dibebani oleh guru dan karyawan SDIT Jabal Nur cukup banyak. Guru dan karyawan yang bekerja full day dari jam 07.15 - 15.30, apabila tidak mendapatkan iklim kerja yang nyaman dan menyenangkan maka bisa menimbulkan kejenuhan dan bosan. Berikut ini pernyataan dari NA sebagai guru senior di SDIT Jabal Nur.

Peran kepala sekolah sebagai climator Sudah baik. Peran penting kepala sekolah harus menciptakan agar adem ayem disekolah karena kita bekerja full day dan hubungan yang baik akan terbina antara guru dengan guru ataupun guru dengan kepala sekolah (NA/22/08/2013).

Jika iklim kerja tumbuh secara sehat maka hubungan yang baik akan terbina. Tugas membina hubungan baik sekolah dengan yayasan, sekolah dengan komite, sekolah dengan pemerintah dan sekolah dengan stakeholder dalam penerapan manajemen berbasis sekolah menjadi peran penting TR. Berikut ini pernyataan IM sebagai guru di SDIT Jabal Nur.

Peran kepala sekolah sebagai climator sudah baik. Ini tugas yang paling berat, sebagai kepala sekolah SDIT Jabal Nur karena harus menyimbangkan antara sekolah dengan yayasan supaya terbentuk iklim yang harmoni (IR/23/08/2013).

Faktor-Faktor yang Mempengaruhi Manajemen Berbasis Sekolah di SDIT Jabal Nur.

\section{Faktor Pendukung}

1. Visi dan Misi Sekolah.

Visi dan misi sekolah ada disetiap ruang yang ada di SDIT Jabal Nur. Tujuanya agar setiap warga sekolah menya- dari dan mengingat akan tujuan mereka bekerja dan belajar di sekolah ini. Visi dan misi di SDIT Jabal Nur pernah mengalami perubahan. Perubahan visi dan misi tersebut akan disusun sesuai dengan kebutuhan dan skala prioritas. Hal tersebut senada yang disampaikan oleh SY sebagai guru di SDIT Jabal Nur.

Penyusunan visi misi dan tujuan, dibuat secara berkala, sesuai dengan kebutuhan kekinian, sehingga visi dan misi dinamis. Ada yang berubah, tetap dan dikurangi (SY/5/9/2013).

2. Hubungan yang harmonis antar warga sekolah.

Iklim kerja yang kondusif, menyenangkan dan penuh kekeluargaan menjadi salah satu faktor yang mendukung untuk mendukung penerapan manajemen berbasis sekolah (MBS). Berikut ini hasil wawancara penulis kepada SY guru di SDIT Jabal Nur.

Suasana kerja kondusif. Artinya Kedewasaan kepala sekolah dalam menyikapi sikap dan sifat asatid sudah cukup baik, dan bisa menjaga situasi yang kondusif dari pribadi yang majemuk (SY/5/9/2013).

3. Peran warga sekolah.

Manajemen Berbasis Sekolah akan berjalan sesuai dengan yang diinginkan pasti membutuhkan banyak sumbangan tenaga, pikiran maupun material dari warga sekolah. Pihak sekolah yang berhak membantu dalam mensukseskan manajemen berbasis sekolah tidak Cuma peran dari kepala sekolah. Dukungan dari warga sekolah menjadi hal yang penting dalam pelaksanaan manajemen berbasis sekolah di SDIT Jabal Nur. Berikut ikut hasil wawancara dengan TK salah satu guru dan juga menjabat sebagai wakasek kurilum.

Semua warga sekolah menjadi aktif sebagai pendukung dan itu menjadi faktor pendorong dalam penerapan manajemen berbasis sekolah di SDIT Jabal Nur (TK/22/ 8/2013).

4. Peran Kepemimpinan Kepala Sekolah

Kepemimpinan yang diterapkan oleh TR seudah cukup baik. TR berusaha mem- 
bagi habis semua pekerjaan kepada warga sekolah SDIT Jabal Nur. Pembagian pekerjaan yang sesuai dengan bidang dan kemampuan yang terkait membuat penerapan manajemen berbasis sekolah lebih efektif.

Berdasarkan wawancara yang dilaksanakan oleh penulis kepada beberapa guru, seperti tertuang dalam laporan peran kepala sekolah pada bab sebelumnya, para guru hampir keseluruhan merasa senang dan puas dengan kinerja dari TR. Kepuasan dan kesenangan guru tersebut akan memberikan dampak yang baik untuk penerapan manajemen berbasis sekolah. Berikut ini penjelasan TR.

Kita mengkoordinasi semua yang ada di SDIT Jabal Nur tanpa ada tekanan dari pihak lain. Saya mencoba untuk seperti itu, jadi pihak luar hanya memberikan masukan dan tidak bisa mencampuri apa yang menjadi keputusan. Kalau masukan kita menerima dengan semua baik wali, yayasan, komite dan masyarakat. Yang penting masukan itu tidak bertentangan dengan SDIT Jabal Nur, itu kita akan pertimbangkan, bahkan kalau masukan itu bagus kita akan melaksanakan. Tapi yang pasti selama ini kita mencoba untuk semua yang kita kerjakan di SDIT jabal nur tanpa ada tekanan dari siapapun (TR/12/9/2013).

Faktor Penghambat

1. Komunikasi yang kurang

Walaupun upaya peningkatan mutu pendidikan dibangun dari berbagai segi, tetapi hambatan tetap ada. Kurang komunikasi dan pembahasan yang mengarah jelas ke manajemen berbasis sekolah. Hal tersebut menjadi hambatan yang banyak disampaikan oleh sebagian guru yang menjadi responden. Berikut ini salah satu guru dengan inisial TK sebagai guru dan menjabat wakasek kurikulum.

Faktor penghambat implementasi MBS adalah komunikasi kurang intens yang ada sangkut pautnya dengan MBS yang internal (TK/22/8/2013).

2. Sumber Dana.

SDIT Jabal Nur Gamping Sleman ini berdiri dibawah koordinasi Yayasan Wali- murid Nurul Ittihad. Sebagian besar sumber sekolah berasala dari orang tua siswa. Jumlah siswa pada tahun 2013/2014 adalah 246 siswa, terdiri dari 11 rombongan belajar (kelas I: 2 rombel, kelas II: 2 rombel, kelas III: 2 rombel, kelas IV: 2 rombel, kelas V: 2 rombel, kelas 6: 1 rombel). Selama ini pendapatan diperoleh dari orang tua siswa untuk SPP selama 1 bulan sebesar Rp. $38.510 .000,00$. Rata-rata iuran siswa per bulan Rp. 156.546,00.

Sumber dana merupakan salah satu kendala bagi program penerapan manajemen berbasis sekolah (MBS) di SDIT Jabal Nur. Selama ini pendapatan sekolah dari 2 sumber, yang pertama dari iuran siswa perbulan dan Bantuan Operaional Sekolah (BOS). Minimnya sumber dana untuk pengembangan mutu pendidikan ini tentu saja menjadi salah satu kendala dalam penerapan manajemen berbasis sekolah.

\section{Simpulan dan Saran}

Simpulan

Dari uraian hasil penelitian pada babbab sebelumnya dapat disimpulkan sebagai berikut.

Pertama, Implementasi MBS di SDIT Jabal Nur. Kepala Sekolah SDIT Jabal Nur kurang intensif dan tegas dalam melakukan sosialisasi implementasi MBS di sekolah yang dipimpinnya. Sosialisasi implementasi MBS tidak dilakukan dalam forum khusus, seperti loka karya, workshop, seminar dan pelatihan pelatihan. Namun demikian kepala sekolah selalu mencoba menerapkan prinsip-prinsip utama MBS, yakni otonomi sekolah dan partisipasi warga sekolah dalam pengambilan dan pelaksanaan keputusan.

Kedua, Kepala Sekolah SDIT Jabal Nur kurang memahami secara detail tentang MBS dan implementasinya. Implementasi MBS di SDIT Jabal Nur masih dalam periode jangka pendek, baru berlangsung selama 2 tahun lebih, dari kepemimpinan kepala sekolah sebelumnya. Dukungan dari yayasan wali murid nurul ittihad yang menaungi SDIT Jabal Nur memberikan ruang gerak yang besar 
kepada SDIT Jabal Nur dalam melakukan otonomi sekolah dan pengontrolan yang dilakukan oleh yayasan wali murid nurul ittihad tidak terlalu ketat.

\section{Peran Kepala Sekolah SDIT Jabal Nur:}

Peran kepala sekolah dalam implementasi MBS yang cukup dominan adalah peran manajerial. Kepala sekolah melakukan fungsi-fungsi manajemen pendidikan bersama-sama warga sekolah, yayasan sekolah dan komite sekolah. Kepala sekolah membuat pembagian tugas dan memberi wewenang kepada tenaga pendidik dan kependidikan yakni tiga orang wakil kepala sekolah, wali kelas, dewan guru, bagian tata usaha, perpustakaan dan bagian keamanan serta pertamanan/tukang kebun. Peran-peran kepala sekolah yang lain kurang intensif dilakukan, seperti peran kepala sekolah sebagai pendidik, manajer, motivator, enterprenuer dam climator.

Faktor-faktor penghambat dan pendukung implementasi MBS

Ada beberapa hambatan yang dialami oleh sekolah dalam implementasi MBS, yakni antara lain: kurangnya sosialisasi, minimnya buku-buku referensi tentang MBS dan kepala sekolah. Adapun yang mendukung implementasi MBS di SDIT Jabal Nur adalah adanya pelimpahan wewenang atau otonomi yang lebih besar dari yayasan walimurid nurul ittihad kepada kepada sekolah serta pemerintah juga memberikan bantuan dana bantuan operasional sekolah (BOS) untuk penambahan biaya operasional disekolah. Kemauan sekolah untuk selalu memperbaiki citranya di mata masyarakat juga merupakan modal utama yang sangat mendukung implementasi MBS, dukungan dari warga sekolah mulai tumbuh baik mulai dari para wakil kepala sekolah, dewan guru maupun staf dan komite sekolah.

\section{Saran.}

Berdasarkan hasil riset terhadap kondisi real yang ada di SDIT Jabal Nur dalam implementasi MBS, maka peneliti membe- rikan beberapa saran sebagai berikut. Pada periode awal implementasi MBS di sekolah, kepala sekolah harus lebih intensif dalam kegiatan sosialisasi sehingga selu-ruh stakeholder mampu memahami dan mengimplementasikan.

Hal ini sangat penting karena keberhasilan dalam sosialisasi akan menentukan keberhasilan langkah-langkah implementasi MBS selanjutnya. Sosialisasi implementasi MBS harus dilakukan secara tegas dan jelas tidak hanya kepada warga sekolah, tetapi juga secara vertikal kepada pemerintah yang terkait sehingga semua pihak akan memberi perhatian dan dukungan yang lebih besar. Kepala sekolah harus mempersiapkan seluruh SDM yang ada agar paham dan mampu menerapkan MBS dengan sebaik-baiknya, baik melalui diskusi, seminar, studi banding dengan sekolah lain, membaca buku tentang MBS ataupun dengan mengirim para staf untuk mengikuti pelatihan-pelatihan tentang MBS. Kepala sekolah dan komite sekolah hendaknya membuat kebijakan-kebijakan baru yang dapat meningkatkan peran serta masyarakat atau wali murid dalam pelaksanaan pendidikan di sekolah.

\section{Daftar Pustaka}

Arikunto, Suharsimi. (2008). Manajemen pendidikan. Yogyakarta: Aditya Media

Bush, Tony \& Coleman Marieanne. (2006). Culture foundation of education; an interdisciplinary exploration. New York: Haper and Brethers Publishers.

Depdiknas. (2000). Manajemen peningkatan mutu sekolah, jilid 1,2,3 dan 4 . Jakarta: Depdiknas

(2006). Manajemen peningkatan mutu berbasis sekolah. Jakarta: Direktorat Pendidikan Menengah Umum

Dharma. (2003). Manajemen berbasis sekolah.; diambil pada tanggal 4 Juli 2013, dari http://www.depdiknas.go.id 
Drummond, H. (1994). Pengambilan keputusan yang efektif, petunjuk praktis dan komprehensif untuk manajemen. Jakarta: Gramedia Pusaka utama.

Fielder, F.E. (1965). A theory of leadership effectiveness. New York: Hill Book Company

Keating, C.J. (1986). Kepemimpinan, teori dan pengembangan. New York: Paulistpress

Moleong. (2001). Metodologi Penelitian Kualitatif. Bandung: Remaja Karya

Kemendiknas. (2007). Standar kompetensi kepala sekolah/madrasah. Jakarta: Kemendiknas

Mulyasa, E. (2007). Menjadi kepala sekolah profesional. Bandung: PT Remaja Rosdakarya

Nurkolis. (2003). Manajemen berbasis sekolah. Jakarta: PT. Gramedia Widiasarana Indonesia.

Rahman. (2006). Peran strategis kepala sekolah dalam meningkatkan mutu pendidikan. Jatinangor: Alqaprint.
Starratt, RJ. (2007). Leaders with vision, the quest for school renewal. San Diego: Corwin Press, Inc.

Sudrajat, Akhmad. (2008). Budaya organisasi di sekolah.; diambil pada tanggal 28 Juni 2013, dari http://akhmad sudrajat.wordpress.com

Oteng, Sutisna. (1993). Adminitrasi pendidikan dasar teoretis dan praktik profesioanal. Bandung: Angkasa.

Usman, Husaini. (2006). Manajemen, teori, praktik, dan riset pendidikan. Jakarta: Sinar Grafika Offset.

Usman, Suhaini. (2010). Konsep dasar MPMBS. diambil pada tanggal 23 Juni 2013, dipublikasikan dalam situs

http://suaidinmath.wordpress.com /2010/04/24/konsep-dasarmpmbs/

Wahjosumidjo. (2001). Kepemimpinan kepala sekolah. Jakarta: PT Raja Grafindo Persada

Wuradji. (2009). The educational leadership, kepemimpinan transformasional. Yogyakarta: Gama Media 